Bryn Mawr College

Scholarship, Research, and Creative Work at Bryn Mawr College

Classical and Near Eastern Archaeology Faculty

Research and Scholarship

Classical and Near Eastern Archaeology

1976

\title{
The Amazon's Belt: An Addendum to a Story of Five Amazons
}

Brunilde S. Ridgway

Bryn Mawr College, bridgway@brynmawr.edu

Let us know how access to this document benefits you.

Follow this and additional works at: https://repository.brynmawr.edu/arch_pubs

Part of the History of Art, Architecture, and Archaeology Commons

\section{Custom Citation}

Ridgway, Brunilde S. 1976. "The Amazon's Belt: An Addendum to a Story of Five Amazons." American Journal of Archaeology 80.1: 82 .

This paper is posted at Scholarship, Research, and Creative Work at Bryn Mawr College. https://repository.brynmawr.edu/arch_pubs/179

For more information, please contact repository@brynmawr.edu. 
rim of the mug is somewhat reminiscent of the upside-down volute palmette which filled the lyre ornament on the rim of the Vlastos amphora. ${ }^{33}$

This study has suggested the attribution of two vases to the Mesogeia Painter-the Houston amphora from the stage of his career when he was becoming a Protoattic painter and the Kerameikos mug from a late stage when he was no longer a major painter. It has also examined the fragmentary Vlastos amphora which is still Late Geometric. The total list of attributions to the Analatos Painter is much longer than the Mesogeia Painter's list, even with these additions. ${ }^{34}$ Yet, as has been shown, there is confusion between the two painters who apparently trained in the same Late Geometric workshop. Perhaps the Analatos list should be reexamined in the light of the new Mesogeia associations.

\section{WRIGHT STATE UNIVERSITY}

Cynthia King

\section{THE AMAZON'S BELT: AN ADDENDUM TO A STORY OF FIVE AMAZONS}

PLATE 16

In a previous issue of this Journal $\left(A J A 7^{8}\right.$ [1974] I-I7) I suggested that the various types of the socalled Ephesian Amazons belong to different dates. In particular, the Berlin-Lansdowne type, to my eyes, seems Classicizing and probably the product of the Augustan period. This theory runs counter to accepted positions and, being largely based on stylistic criteria, is incapable of definite proof.

An element exists, however, which may prove useful in determining the correct date of the type. During a recent visit to the University Museum of Classical Casts in Cambridge, England, I had the opportunity to see side by side several replicas of the various Amazon types, and noted that all seem consistent in reproducing a specific form of belt for each type in all its copies. Thus the Mattei Amazon uses a flat band tied with a Herculean knot, with loose ends hanging. The Capitoline type has just the flat ribbon, with no visible tie. But the Berlin-Lansdowne type wears a thin belt, almost tubular in section, which looks like a leather thong. This leather strip loops around a hook at each end of a rectangular buckle, obviously meant to reproduce a metal type: its long sides curve inward, the short sides have a series of three rivets fastening the hooks, of which one curves down, the other

I74, pl. 42a. Pl. I4 A bottom is Munich, Antikensammlungen 6077, krater; see also Kübler, Ker. VI. 2, 620, no. 290; Hampe, fig. I7; E. Akurgal, The Birth of Greek Art (London: Methuen I 968) I77, pl. 5 I (color).

${ }^{33}$ Supra n. I 8 . Kübler, Ker. VI. 2, fig. 32 on 349 ; he remarks on the use of the lyre ornament's stuffing as an independent ornament, I33.

34 Attributions to Analatos Painter: Cook, BSA 35 (19341935) 166-76; Hampe, 31-32; Davison, 51-52; Brann, AJA 6o (1956) 74; AJA 64 (1960) 7I-72; $A g$. VIII, 4-5, ro. Attributions to Mesogeia Painter: Cook, BSA 35 (1934-1935) I76-79; upwards. A central knob may be a further ornament (pl. r6, figs. I and 2).

This belt looks so distinctive, and is so consistently reproduced in all its details, that we may assume it formed part of the original bronze statue. Were it to be shown that this form of belt came into use at a specific time, at least a terminus post quem could be gained for the original composition. I have been unable to obtain general information on belts, or to read Doris Stupka, Der Gürtel in der griechischen Kunst, Doctoral Dissertation Vienna 1972 (listed in $A A$ 1973). However, Dr. Stupka has kindly informed me that, to her knowledge, this belt form appears only on the replicas of the Lansdowne type (among which one should therefore definitely include the Ephesos relief in Vienna, which displays a similar fastening). Thus Dr. Stupka used the traditional chronology of the Amazon to date the belt type, rather than vice versa. She further commented that she knows of no parallels in Roman art, and that belt buckles or hooks are rare even for Greek belts. This note is meant as a plea to elicit some information from $A J A$ readers at large, in the hope of throwing some light on the problem.

\section{BRYN MAWR COLLEGE}

Brunilde Sismondo Ridgway

\section{A NOTE ON SKIAGRAPHIA}

Eva Keuls's article on skiagraphia ${ }^{1}$ argues that the painting of Apollodoros was an ancient version of the divisionism of the later nineteenth century. Her hypothesis is based on the association of diverse passages from Plato and Aristotle. The latter offers the scientific basis of Keuls's theory. In de Sensu, there is description of the three means of color gradation: mixture, superposition, and juxtaposition. ${ }^{2}$ But only one, superposition $\left(\dot{\epsilon} \pi \iota \pi 0 \lambda \eta^{\prime}\right)$, is discussed in direct connection with painting. Aristotle also seems to have known of the additive nature of color, from observation of the rainbow. ${ }^{3}$ This theory of additive color was rediscovered by Chevreul and formed part of the divisionist theory of color used in later nineteenth century painting. ${ }^{4}$ However, none of Aristotle's work on color and light includes an equation with skiagraphia.

There are, of course, many references to skiagraphia in pre-Hellenistic writers, ${ }^{5}$ but they are primarily metaphors in Plato and Aristotle to specify illusions: to contrast things unclear in a close-up view with

$B S A 42$ (1947) I4I-43; Gnomon 34（I962) 821-22; Brann, $A g$. VIII, Iо; S.M. Burke, "A Protoattic High Standed Bowl in Buffalo," $A J A 78$ (1974) 63-65.

\footnotetext{
1 Eva Keuls, "Skiagraphia Once Again," $A J A 79$ (I975) I-I6. Hereafter, Keuls.

2 Keuls 6, I 2.

3 In the Meteorologica; Keuls 6, I5.

4 Keuls 3-4.

5 Cited by Keuls, and see especially J. Pollitt, Ancient View of Greek Art (New Haven 1974) 247-54. Hereafter, Pollitt.
} 


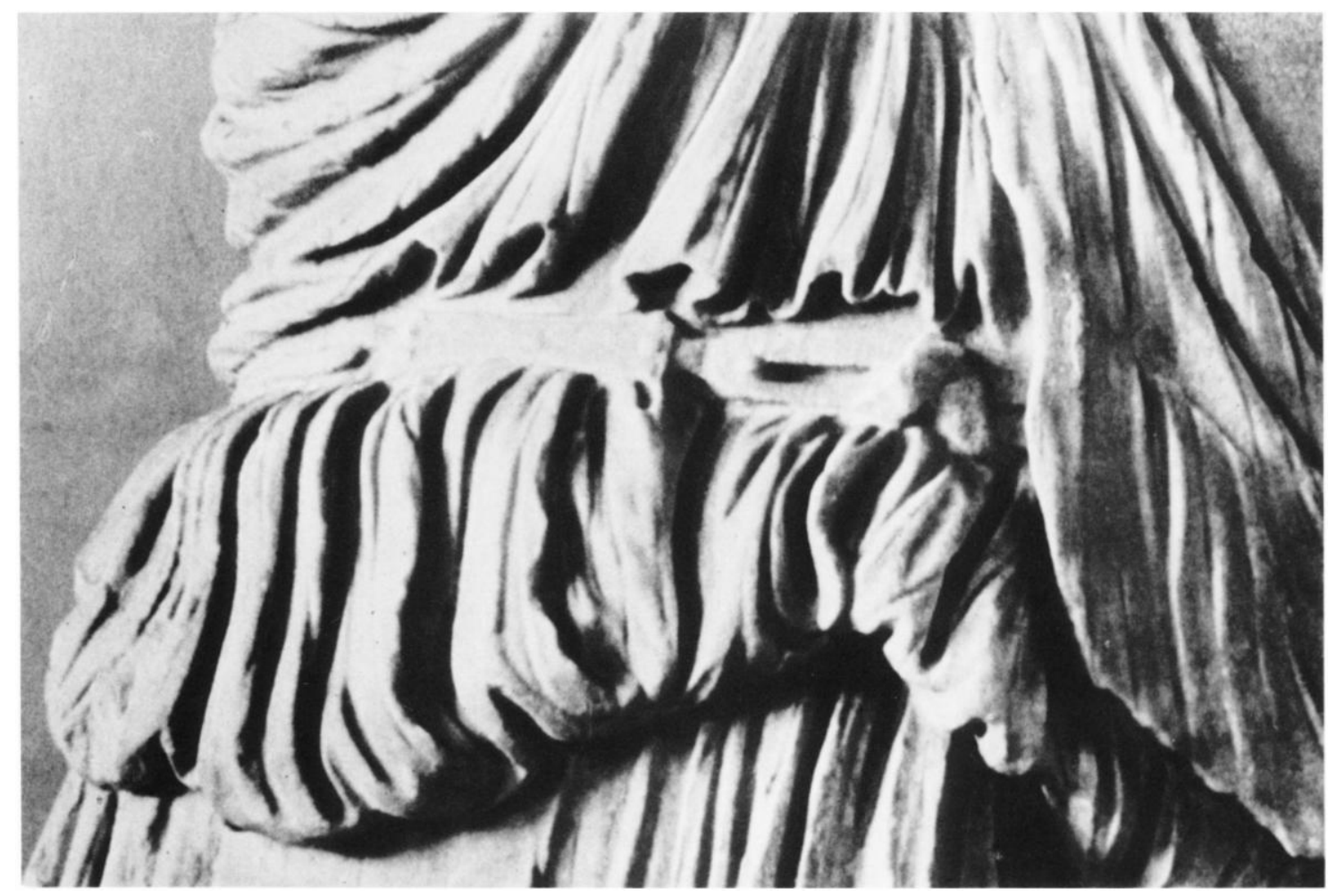

Fig. I. Detail. Lansdowne Amazon in Metropolitan Museum, New York. Photo Karl Dimler, Bryn Mawr College

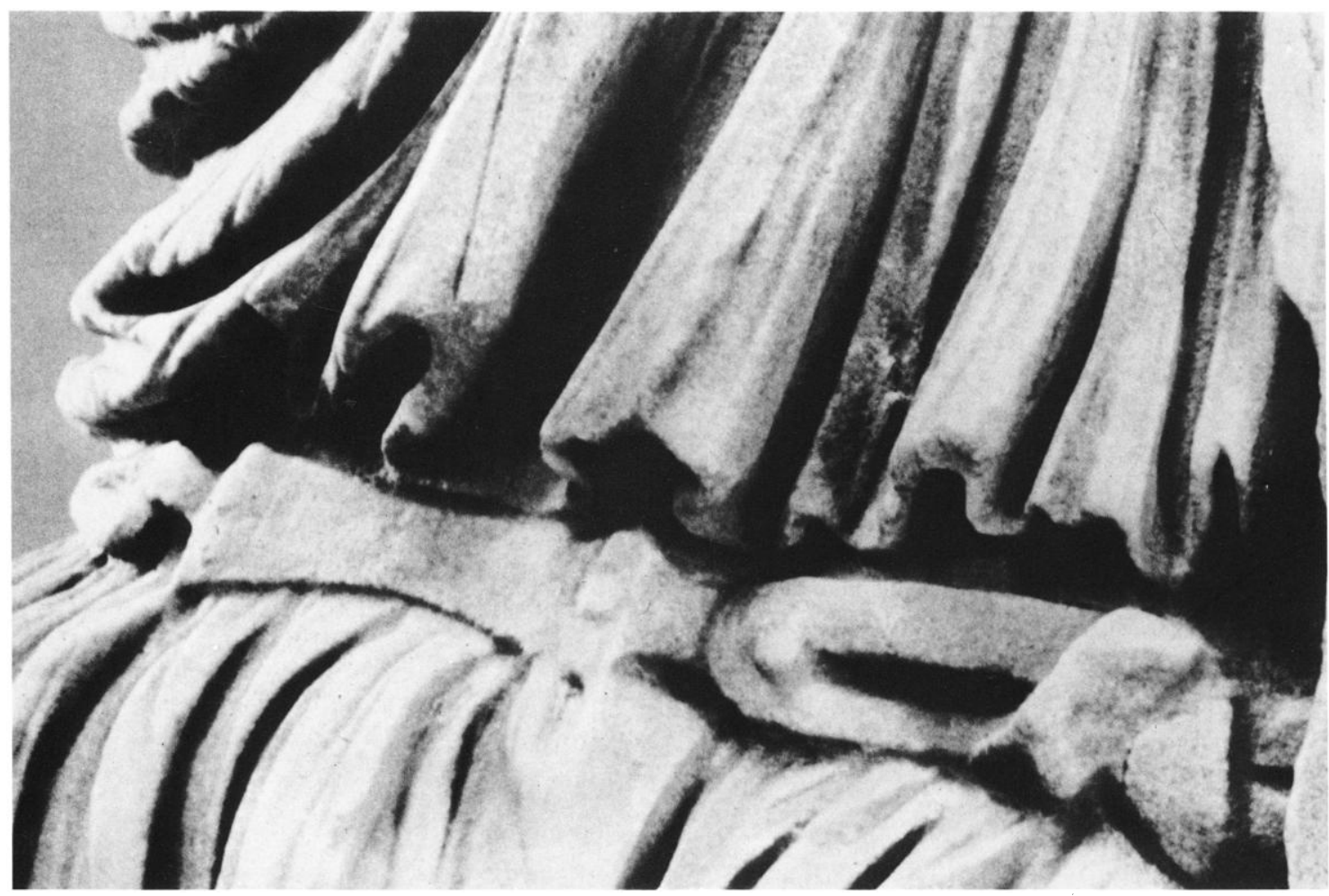

Fig. 2. Detail. Lansdowne Amazon in Metropolitan Museum, New York. Photo Karl Dimler, Bryn Mawr College 